

\section{Shirkah}

Journal of Economics and Business

Vol. 2, No. 1, January-April 2017

ISSN: 2503-4235 (p); 2503-4243 (e)

\section{Editor in Chief}

Sri Walyoto

\section{Editorial Boards}

Abu Umar Faruq Ahmad, UBD School of Business and Economics, Brunei Darussalam

Amelia Fauzia,

Asia Research Institute, National University of Singapore, Singapore

Cedomir Nestorovic,

ESSEC Business School Asia Pacific, Singapore

Dwi Condro Triono,

Faculty of Islamic Economics and Business, IAIN Surakarta, Indonesia

Fahmy Radhi,

Faculty of Economics and Business Universitas Gadjah Mada, Yogyakarta,

Indonesia

Hasan Basri,

Syiah Kuala University, Aceh, Indonesia

Johan Fischer,

Department of Social Sciences and Business Roskilde University, Denmark

Masudul Alam Choudhury,

Postgraduate Program in Islamic Economics and Finance, Trisakti University,

Jakarta, Indonesia and the College of Economics and Political Science (CEPS) in

Sultan Qaboos University (SQU), Oman

M. Falik Isbah,

School of Humanities and Social Science, University of New South Wales, Australia M. Ishaq Bhatti,

La Trobe Business School Department of Economics and Finance La Trobe

University, Australia

Najib Kailani,

Pascasarjana, Universitas Islam Negeri (UIN) Sunan Kalijaga, Yogyakarta, Indonesia 
Nunung Nurul Hidayah,

Aston Business School, Aston University, Birmingham, United Kingdom

Shaikh M Ghazanfar,

Departement of Economics, University of Idaho, Russian Federation

\section{Managing Editors}

Fitri Wulandari

Jasanta Perangin-angin

\section{Assistant to Editor}

M. Endy Saputro

M. Zainal Anwar

Supriyanto

Shirkah Journal of Economics and Business is a peer-reviewed journal published three times a year (January-April, May-August and September-December) by Faculty of Islamic Economics and Business, Institut Agama Islam Negeri (IAIN/ State Institute for Islamic Studies) Surakarta Central Java, Indonesia. The main objective of Shirkah is to offer an academic space of exchange ideas and initiate the increase number of qualified article produced by postgraduate students, practitioners and academicians.

\section{Editorial Office}

Ruang Jurnal Shirkah

Ground Floor, West Gate,

Faculty of Islamic Economics and Business

IAIN Surakarta

Jln. Pandawa No. 1, Kartasura, Sukoharjo, Jawa Tengah Kode Pos. 57168

Phone (+62271) 781516 Fax: (+62271)782336

E-mail: shirkahiainsurakarta@gmail.com

Website: http://shirkah.or.id/ 



\section{Shirkah}

Journal of Economics and Business

Vol. 2, No. 1, January-April 2017

ISSN: 2503-4235 (p); 2503-4243 (e)

\section{Table of Contents}

\section{Articles}

Ana Zahrotun Nihayah

Savings and Loans Program, The Revenue of Small Micro Entreprises and Poverty Reduction among Women Groups

Ana Fadhilah

Muslimah Entrepreneurship and Economic Empowerment in Pengajian

Umiyati

Local Economics Empowerment and Sharia Microfinance in Rural

Community Perception

Lathif Hanarif Rifqi

Community Empowerment through Islamic Microfinances Perceptions in Comparison

Ahmad Lukman Nugraha

Islamic Business Ethics and Islamic Microfinance in Pesantren Gontor

Nova Ch. Mamuaya

Service Quality and Non-Muslim Satisfaction Using Sharia Bank Products and Services 



\title{
Savings and Loans Program, The Revenue of Small Micro Entreprises and Poverty Reduction among Women Groups
}

\author{
Ana Zahrotun Nihayah \\ Islamic Economics, Graduate School, Universitas Gadjah Mada \\ ananihayah89@yahoo.com
}

\begin{abstract}
This research aims to understand the micro small medium business income both before and after receiving the program, to find out the number of poverty reduction, and to see the application of Islamic economic values on the women's saving and loans program. The population of this research are members of the women's saving and loans program, which is 215 people in total and scattered in 16 business group. Using random sampling techniques, there are 70 people that was taken into consideration. The method analysis used in in this research is using Wilcoxon rank test analysis, the poverty reduction analysis, and the Islamic economics values. Based on data analysis is(1) founded that the women's saving and loans program affecting the micro small medium enterprises income. (2) Due to the women's saving and loans program there are decreasing number of poverty rate about 20 percent. (3) It is realized that there are some applications of Islamic economics values upon the women's saving and loans program, they are time extensions, fine replacement, social activities, and the improvement of society welfare.
\end{abstract}

Keyword: micro small medium business, Islamic economic values, saving and loans program

\section{Introduction}

Small and medium enterprises in Indonesia's economy are the largest employment provider (The Ministry of cooperatives and SMEs, 2005). Its position is as a major player in the economic activity in the various sectors. In the development of economic activities and local community empowerment, it was an important player that creating of 
new markets and sources of innovation. Therefore, the smalland medium enterprises contributions maintains the balance of payments through the export activities (Sulistyastuti, 2004).

The small and medium enterprise is considered to be bulletproof despite its myriad challenges and its problem. Various problems experienced by small and medium enterprise include capital, marketing, raw materials, technologies, management, bureaucracy and partnerships (Primiana, 2009). The same study carefully argues that the Women's Saving and Loan Program imposed by the Government can address the problem of capital for small and micro enterprise (Yusuf,dkk, 2010). There is a difference in the level of income between small merchants who have the loan recipients and small merchants who are notthe recipient of the PNPM Mandiri Pedesaan. Average income earned by small merchants who are the recipient of loan of SPP Program is greater than average income of small merchants who are not the recipient of the PNPM Mandiri Pedesaan. In addition, the program also affects the increase of society revenue.

The phenomenon of rural poverty is not a new phenomenon. The number of Indonesia's population living under the poverty line still showed a relatively large number. Based on the data of the Central Bureau of Statistics (BPS) in March 2013, the number of poor people in Indonesia is amounted to 28.07 million people $(11,37 \%)$, which 62,76 per cent of them are in the rural area (Setyagraha, 2014). Majority of poor people in the productive age are low-educated, low-skilled and little capital. Small and micro enterprise sector are strategic area to solve this problem (Akyuwen, Roberto, Krisna Wijaya, 2010). The number of labor absorbed by the micro, small, medium and large sector are as follows: 


\section{Table 1}

\section{The Contribution of Labor Absorption by Micro, Small, Medium, and Large in Indonesia, 2011 and 2012}

\begin{tabular}{|l|l|c|c|c|c|c|c|c|}
\hline \multirow{2}{*}{ No } & \multirow{2}{*}{ Sector } & \multirow{2}{*}{ Unit } & \multicolumn{2}{|c|}{2011} & \multicolumn{2}{c|}{$\mathbf{2 0 1 2}$} & \multicolumn{2}{c|}{$\begin{array}{c}\text { Expansion in } \\
\text { 2011-2012 }\end{array}$} \\
\cline { 5 - 10 } & & & Jumlah & $\%$ & Jumlah & $\%$ & Jumlah & $(\%)$ \\
\hline $\mathbf{1}$ & Micro enterprises & (Unit) & 94.957 .797 & 90,77 & 99.859 .517 & 90,12 & 4.901 .720 & 5.16 \\
\hline $\mathbf{2}$ & Small enterprises & (Unit) & 3.919 .992 & 3,75 & 4.535 .970 & 4,09 & 615.977 & 15.71 \\
\hline $\mathbf{3}$ & Medium enterprises & (Unit) & 2.844 .669 & 2,72 & 3.262 .023 & 2,94 & 417.354 & 14.67 \\
\hline $\mathbf{4}$ & Macro enterprises & (Unit) & 2.891 .224 & 2,76 & 3.150 .645 & 2,85 & 259.422 & 8.97 \\
\hline & Total & (Unit) & 104.613 .681 & 100 & 110.808 .154 & 100 & 6.1994 .473 & 5.92 \\
\hline
\end{tabular}

Source: Data of Ministry Cooperation RI (2012)

Economic activities in the rural area are dominated by small and micro enterprise sector in agriculture, trade and industry. However, the businessmen still have capital difficulty (Hamid, 1986). They are difficult to acces capital from formal financial instituion because they are not bankable or does not meet the requirements of lending. One of the main activities of the PNPM Mandiri Pedesaan is allocates Bantuan Langsung Masyarakat (BLM/ Direct Subsidiaries for Society) to each district in Indonesia (Qardhawi, n.d.). The BLM is distributed in the form of business capital. It is effective to improve economic productivity.

Differences in the extent of human life is a blessing as well as a reminder to every human group with the aim to complement each other, in that it is a group that satisfied his level or more powerless can help with underprivileged groups so it will create social interaction in the society. Allah said in surat al-Zukhuf (43):

Whether they are feasting on Allah's grace? We have specified between them their livelihood in the life of the world, and we've raised some of them over some of the other to some degree, so that some of them could use some others. Your Lord and mercy is better than what they collect. (Q.S. Az-Zukhuf: 32) 
Islamic economics with testimony to the existence of differences in income saw that among the principle of justice are to hold the gap between the poor and the rich in the community to create balance, to turn off the fire of jealousy and to avoid social anger (Qardhawi, n.d.). Allah says in the Qur'an surat al-Hashr (59) as follows:

What are the treasure spoils (fai-i) is given by God to his Apostles (of property) that comes from the inhabitants of the cities, it is for God, for the Apostle, the kin, orphans, poor people and people who are on the way, so that the treasure be circulated among the wealthy among you. What is given to you, then just accept the Apostle. and what ban you, Then leave. and fear Allah. Allah is very hard punishment. (Q.S. al-Hashr: 7)

The verse describes the principle of wealth distribution. In the Islamic system of life, wealth should be shared to all classes in the society and should not be a commodity among the rich only.

Based on the above background, the author is interested in studying more about the influence of the saving and loan program for women against the small micro enterprise revenue in the economic perspective of Islam. Taking PNPM Mandiri Bangilan district Tuban Regency, East Java, Indonesia, this study focuses on such assumption as that the women's saving and loan program have an impact on the income of small micro enterprises; the women's saving and loan program have an impact on reducing the number of poor households; and there was an Islamic economic values contained in the women's saving and loan program.

This research is descriptive research using survey to gather data and statistics (Kuncoro, 2011) Descriptive data is generally collected through a list of questions in the survey, interview, or observation (Kuncoro, 2009). This research was conducted at one village located in district Bangilan district Tuban Regency is Sidokumpul village. The village of Sidokumpul 
has 16 groups of recipients of the women's saving and loan program. The object of the research was the women's saving and loan program PNPM Mandiri Pedesaan followed groups of women in the village.

The population used in this study is all the borrower of the women's saving and loan program in Sidokumpul village, which comprises 16 groups. Each group contains 8 to 15 people, bringing the total overall loan recipients to 215 people. Researcher only uses data in 2014 (Sidokumpul, n.d.). Determining the sample size in the study by Slovin (Sevillia, 1993) as follows:

$$
n=\frac{N}{1+N e^{2}}
$$

$\mathrm{n} \quad$ : the sample size

$\mathrm{N} \quad$ : tha population size

e $\quad$ :standar eror (10\%)

then the number of sample is $n \frac{215}{1+215(0,1) 2}=68,253(70)$

Based on the calculation, the number of samples obtained as much as 68,253 rounded into a 70 , bringing the total sample research is 70 people in the village of Sidokumpul. Sampling technique used is random sampling so that every individual has the possibility of sample or the same for selected at random (Herdiansyah, 2012). Because the loans are funding the group, there are 16 villages in the Sidokumpul group, and each group contains 8-15 people. The overall Total was 215 people. To represent members of a population then the sample of 70 people are taken from all group, 3-5 people from each group.

Primary data in this study were obtained directly from an interview with chairman of the executive unit activities and a group leader. Primary data is also obtained from questionare distributed to customer of the 
womens's saving and loan program. Whereas, the secondary data obtained from studies of various literature and related documents, such as districts statistical data, BPS data, and data related to program PNPM Mandiri Pedesaan of Bangilan district. Questionnaires is distributed directly to group leader. Then questionnaire distribution to each group member was done by the group leader. Interviews with all group leader were conducted according to the questionnaire prepared by the researcher. The question asked was about the operational mechanism of women's saving and loan program to analyze Islamic economics principles attached in it.

The data was analyzed by three methods. First, Wilcoxon signed rank test, it was used to compare two paired sample of interval scale without normal assumption. The data examined came from some of the same respondents and pertain to the different observation periods (before and after program). Second, Poverty Reduction Analysis method. The number of poor households after program was known by calculating percapita income for each household. It is by dividing income by the number of family members. A household is belong to poor definition if the percapita incomes below the poverty line and vice versa. After the number of poor houshold is known, Head Count Ratio (HCR) or a percentage of the poor population is calculated. Poverty measurement is based on the poverty line in the base year and the year of evaluation. Poor people are those whose income is below the poverty line (Suyanto, 2013). Third, the women's saving and loan program was analized with economic value of Islam in the program, including the mechanism aspects and the program's influence to the society.

\section{Islam Overcoming Poverty}

Poor is defined as people who has no treasure and lean (low income) (KBBI, 1999), while needy is defined as people who are in need, people 
who are very poor, people who deliberately make him suffer deprivation to achieve inner perfection (KBBI, 1997). According to Hanafi, needy is someone who have assets of less than nishab, even if he is healthy and has a job (Mughniyah, 2002). The Quran (al-Baqarah) explains:

(infaq) to poor people who are bound (by jihad) in the way of God; they can not (trying) on Earth; people who don't know think they are rich because people kept themselves from ask. You know them by viewing its properties, they are not asking to be urgent. And what a good treasure what you spend (in the way of Allah), then surely, Allâh is all know us. (Q.S. al-Baqarah: 273)

There are many programs in poverty reduction but in fact the problem of poverty is still considered as serious problem esepecially for developing countries (Mariyanti, 2016). Definition of poverty is expressed by some experts. Poverty is the shortage of goods and services required to achieve a decent standard of living. Due to the standard of living is different; there is no definition of poverty universally accepted. Bradly R. Schiller describes that poverty is the inability to get goods and services adequate to meet social needs (Ala, 1996). Based on some of these definitions, it can be concluded that poverty is inability to fulfill basic necessities caused by lack of income.

One of the methods used to classify people as poor is using poverty line. BPS using the concept of basic needs in fulfilment (basic needs approach). With or another, poverty is considered as an inability in fulfilling the basic needs of food and non-food which is measured in terms of expenditure. So it can be concluded that, the poor population is a population that has an average income below the poverty line (BPS, 2014). The table is a listof poverty line for three (3) areas in Java. 


\section{Table 2}

The poverty line based on villages in Indonesia, 2013

\begin{tabular}{cccc}
\hline Source & $\begin{array}{c}\text { Poverty Line in } \\
\text { East Java }\end{array}$ & $\begin{array}{c}\text { Poverty Line in } \\
\text { Central Java }\end{array}$ & $\begin{array}{c}\text { Poverty Line in } \\
\text { West Java }\end{array}$ \\
\hline BPS & Rp.269.294,- & Rp. 256.368,- & $268.251,-$ \\
\hline
\end{tabular}

Source : BPS 2013

In Islam, solutions for poverty reduction are divided into two groups, responsibility of everyone and responsibility of the community (Adnan, 2015). Responsibility of everyone to pay attention to the root of the word "poor", main factor causing poor are the attitude of silence, reluctant, or inability to move and seek. Al Qur'an (al-Jumuah) explained:

When the prayer ended, then have scattered thee on the Earth, and seek the grace of God and remember God as much as possible so that you may get lucky (Q.S. Al-Jumuah: 10).

Then, responsibility of the community that poverty reduction can be done by distributing zakat. In this case, the Quran although it advocated voluntary donations, in some ways, Al-Qur'an emphasizes the rights and obligations. Zakat is one of these obligations. Al Qur'an in Surat Al-Maidah (2) explains:

Indeed, the zakat-charity is for poor people, poor people, the board of managers of the zakat, mu'allaf who persuaded him to (liberty) slaves, those in debt, for cause of God and for the stranded traveler, as a statute that required of God, and God is Omniscient wisdom (Q.S. At Taubah: 60).

Both are interconnected so as to require awareness and coordination of all citizens. 


\section{Empowernment of Women and Income Level}

Women's empowerment program should be done on an ongoing basis by involving all elements of society, no exception of men (Sakai, 2010). In the women's empowerment program, right approach is needed in accordance with the targeted community groups. Such approaches are needed to improve the women's bargaining power in changing his fate (Atal, 2017). Islam not only in respect of the activities of the economy for women and men to obtain property and earnings, even Islam to motivate and exhorts men and women to perform the economy actively. Al-Qur'an (At-Taubah) explains:

“And say, 'You,' the Work of God and his Messenger and the believers will see your work, and you will be returned to (God) who knows the unseen and will manifest, and then preached unto you what ye used to do. (Q.S. at-Taubah: 105)

Allah advocate to work to all his servants, men as well as women for the women who work, it is good for her because it can help the economy of the family, while men gained favor for allowing his wife to work.

Income is the inflow of treasures (assets) arising from delivery of goods or services carried out by a business unit for a certain period, the basis used to measure the magnitude of the revenue is the amount of cash or its equivalent is received from the sales transaction with the non-party, the terms therein contained income is the amount of volume of goods sold multiplied by the price of goods before deducting expenses (Baridwan, n.d.).

Understanding the income indicator is important to know the success rate of an activity is the economics. Generally, income can be classified into three, namely: a). Salaries and wages; the rewards that accrue to someone after doing a job for someone else, a private company or the 
government; b). Income from wealth; revenue from the business itself that is the value of total production, reduced by costs. Labor from family and capital lease are not taken into account; c). Income from other sources; it is obtained without the shedding of labour, among others, the acceptance of Government, unemployment insurance, lease assets, bank interest and other in-kind donations (Samuelson, n.d.).

The women's saving and loan program is one of of some program of PNPM Mandiri Pedesaan. The fund of the program is 25 percent from BLM fund. Target of the program is poor households who require fund for their productive business activities. Seventy people were taken as sampel from the total population of 215 people. They are all the participant SPP program of PNPM Mandiri Pedesaan in Sidokumpul village sub district Tuban Regency Bangilan. Respondents characteristics based on data gathered are as follows:

\section{Table 3}

Characteristic of Respondents

\begin{tabular}{|c|c|c|}
\hline Characteristics of Demographic & Total & $\%$ \\
\hline Age & & \\
20-30 year & 10 & $14,29 \%$ \\
31-40 year & 28 & $40 \%$ \\
41-50 year & 25 & $35,71 \%$ \\
51-60 year & 7 & $10 \%$ \\
\hline Level of Education & & \\
Unaducated & 8 & $11,43 \%$ \\
Elementary School & 37 & $52,86 \%$ \\
Primary School & 6 & $24,28 \%$ \\
High Scool & 2 & $8,57 \%$ \\
University & & $2,86 \%$ \\
\hline Kinds of Effort & 6 & \\
Industry & 64 & $8,57 \%$ \\
Trader & \multicolumn{2}{|}{} \\
\hline \multicolumn{2}{|r|}{}
\end{tabular}




\begin{tabular}{|c|c|c|}
\hline Duration of Effort & & \\
$1-4$ year & 20 & $28,57 \%$ \\
$5-10$ year & 29 & $41,43 \%$ \\
$11-20$ year & 14 & $20 \%$ \\
$21-30$ year & 7 & $10 \%$ \\
\hline
\end{tabular}

The results of two sample paired Wilcoxon test is showed in Table Output SPSS Test. It gives insight to the difference of income, before and after the loan from PNPM.

Table 4

Output SPSS Test Statistics

\begin{tabular}{|l|c|}
\hline & After Program-Before Program \\
\hline$Z$ & $-7,255^{\mathrm{b}}$ \\
Asymp. Sig. (2-tailed) &, 000 \\
\hline
\end{tabular}

It may be seen from the table that $Z$ value obtained is $-7,255$. Using alpha 5 percent, $H_{0}$ is rejected because $Z$ value fall outside acceptance region which is between -1.96 and 1.96. It can be concluded that the difference of amount of income, after and before the program, is significant. The $\mathrm{p}$ value is 0.000 which is less than 5 percent. It can be concluded that $\mathrm{H}_{0}$ is rejected and this means that there is a significant change of income before and after program.

It is in line with the data obtained from the respondents. The respondent's average income was rise 36.4 percent, from $\mathrm{Rp} 966.571,42$ before receiving loans become Rp 1.520.000 after receiving loan from SPP program.

Table 5

Average Income before and after the Women's Saving and Loans

Program, 2014

\begin{tabular}{|l|l|l|c|}
\hline No & \multicolumn{1}{|c|}{ Description } & the average income & Increase of income \\
\hline 1 & Before Program & 966571,42 & \\
\hline 2 & After Program & 1520000 & \\
\hline 3 & Increase of average income & & 553428,58 \\
\hline
\end{tabular}

Vol. 2 No. 1, January - April 2017 
Loan capital was spent in the form of various types of merchandise by respondent whose profession is a trader. Increase in merchandise increase their income. In doing so, it is applied to industry sector. The industrial sector in Sidokumpul village is tofu and tempe. Additional capital from the loan of SPP Program was used to buy more raw materials that resulted in increase of production and income.

To find out how much the poverty reduction after PNPM Mandiri Pedesaan especially the SPP program. Calculation of poverty reduction (PR) is done. Per-capita income is compared with the poverty line to find out the number of household which categorized as poor. The following table showing the calculation of poverty reduction (PR):

\section{Table 6}

Poverty Reduction Indicator

\begin{tabular}{|c|c|c|c|c|c|c|}
\hline No. & Explanation & $\begin{array}{c}\text { Poor } \\
\text { Resident }\end{array}$ & $\begin{array}{l}\text { Amount of } \\
\text { Respondent }\end{array}$ & $\mathrm{HCR}_{1}$ & $\mathrm{HCR}_{2}$ & $\begin{array}{c}\left(\mathrm{HCR}_{1}-\right. \\
\left.\mathrm{HCR}_{2}\right) / \\
\mathrm{HCR}_{1}\end{array}$ \\
\hline 1 & Before Program & 10 & 70 & 0,142857 & & \\
\hline 2 & After Program & 8 & 70 & & 0,114286 & \\
\hline 3 & Poverty Reduction & & & & & 0,2 \\
\hline
\end{tabular}

Based on the above calculations, poverty reduction is equal to 0.2 . It means that the decline of poor population is 20 percent after program. Decrease in the number of poor people by 20 percent indicates that the program did not succeed in their goal of poverty reduction, since there were still 80 percent of society that still fall into the categories of the poor. This failure is caused, at least, by 1). Capital loans granted to the poor is not offset by the assessment in the form of monitoring as well as skills training. It causes ineffective use of funds. There is lack of attention from the organizer activity against sustainability loan channelled. Similar to formal finance institutions, PNPM Mandiri Pedesaan only supplies fund without making sure whether the fund is used correctly or not. 2). The business of Program SPP's participant is not growing, but on the other 
hand they have to bear the burden of repayment of loan principal as well as the interest of 1.5 percent.

Other factors are 3). Profession of some participants of SPP Program is pulse merchants and fried snacks in the local village primary school. The existence of the program was only able to increase revenues without removing them from the problem of poverty. 4). Awareness of society in managing loans is less than optimal. It is triggered by the culture of the poor who do not want to grow. The poor community groups are included in the categories of types of cultural poverty, poverty which is caused by lifestyle, living habits, and cultural life of a person or groups of people. They are already feel well off and do not feel deprived. People of this kind is difficult to participate in development, because most of them do not want to increase their standard of living. 5). Institutions and local figures do not care about the success of the program. The reason is that they do not feel that it is their concern and there is no responsibilities charged on them.

Based on the interviews that have been done with the chairman PNPM Mandiri Pedesaan and and the chairman of the executive unit activities, it can be drawn that the Islamic economic values in the program are as follows giving grace period and not incur fines; in case of bad debts caused by the inability of the customer in paying off the principal loan payments.

The chairman of executor came to group to questioned why the payoff is experiencing congestion, then the PNPM-MP gives a grace period and an affidavit which contains the ability of paying off the arrears before the end of the book-closing period (Interview 30 June 2013).

In Islamic economics perspective, when borrower had difficulties in debt payments, grace period is given, according to surat al-Baqarah (2): 
And if (the person who owes it) in the lurch, then give respite until he is able to pay. And give (some or all of the debt), it is better for you, if you are know (Q.S. al-Baqarah: 280)

In this verse, Allah ordered to be patient and give a grace period when the borrower has difficulties in debt payment. Give a grace period is highly recommended in Islam, and then if you want to free up its debts then it will be better. Similarly, in the hadith mentioned about the virtue of the people who give a grace period for a person who is difficult to pay off the debt.

PNPM Mandiri Pedesaan does not impose a fine when the borrowers experiencing difficulty in payment of its obligations. In Islamic economics, when a borrower can not afford to pay and the lender gives the borrower time to pay with an additional amount outside the loan principal as requirement, it is usury. It is in accordance with the words of the Prophet, "Whoever gave waivers to people who owe him or even waive debts, then he'll get shade 'Arsy on the day of resurrection" (Sahih Ibn Majah, no. 1963).

On the other hand, although the PNPM Mandiri Pedesaan gives dispensation for borrowers who are having trouble, but to suppress high bad credit rate, then the PNPM Mandiri Pedesaan gives a reward or incentive for customers who pay on time on loan repayments each month. It is named incentive payments on time. The magnitude of it is 2.5 per cent of total services. Al-Qur'an (al-Baqarah) explains:

Who would want to lend loan to Allah a good loan (goodly in the way of Allah), Allah of folding the duplicate payment to him by the multiplier doubles the corpulent. And God narrowed its and broadened (sustenance) and in whom ye returned (Q.S. AlBaqarah: 245). 
It is in tune with the social activities conducted annually by the PNPM Mandiri Pedesaan by giving staple food to poor people for free. These funds are taken from the profits obtained from the client services on the womens's saving and loan program in theamount of 15 percent. In the context of Islamic Economics, it can be called as shodaqoh.

PNPM Mandiri has been improving the welfare of society. It is in accordance with the words of the Prophet, "A muslim is the brother of another muslim, he is not wronged him in order. Whoever meets the needs of his brother, Allah will meet necessary. Whoever removes a narrowness of the narrowness of the narrowness of the world-a muslim, Allah will remove him from the narrowness of the narrowness of one - the narrowness of the day of judgement. He covered the evil muslim, Allah will cover the shortcomings on the day of resurrection" (Al-Bukhari and Muslim).

In Islam, any activity carried out must have goals to meet the needs of other society (Wahyudi, 2015). Program SPP's objectives are fulfilling the needs of the community with the loan and also raising welfare, for such reason as 1). an increase in revenues as well as reduce the displacement of village to city, which is usually done during the dry season and 2). weak economics of the traders community regardless of the trapping of the renternir.

\section{Conclusions}

This research of the Islamic economic perspective of savings and loans program for group of women towards the revenue of small micro entreprises and poverty reduction produced some conclusions. First, the granting of loans on the women's saving and loans program influence against a small micro enterprises income change. Wilcoxon sign rank test results explained that the $\mathrm{p}$ value is of 0.000 which is less than alpha of 0.05. In turn, $\mathrm{H}_{0}$ is rejected and it means that there is a significant change 
of income before and after loan. According to the data obtained from the respondents, that before receiving loans from the program, average income are $\mathrm{Rp} 966.571,42$ increases after receiving program to $\mathrm{Rp} 1.520 .000$ or increased by fare was 36.4 percent.

Second, women's saving and loans program in PNPM Mandiri Pedesaan influence on poverty reduction. The latter is proved by the calculations of indicators of proverty reduction through a per-capita income of respondents with measurements as compared with the poverty line so as to obtain numbers poverty reduction by 20 percent. This means going on poverty reduction by 20 percent on the loan recipients women's saving and loans program.

Third, based on the analysis of the results obtained, the economic values of Islam in the women's saving and loans program include the granting of time lag on the customer's payment difficulties, no penalty on account holders who pay principal and loan services not in time, running social activities i.e. providing staple food for the poor and improving the welfare of the community.

Women's saving and loans programin PNPM Mandiri Pedesaan proven positive effect against small micro enterprises income change, so that the program needs to be continued and expanded to provide the opportunity for households who have not had the opportunity to ask the loan program of PNPM Mandiri Pedesaan. From the research that has been done is found a deduction rate of poverty by 20 percent, it shows that the process of awarding women's saving and loans program has not been successful in alleviating poverty, since there are still $80 \%$ of the total poor who haven't come out of poor categories. Therefore, it is useful to recommend PNPM Mandiri Pedesaan to give counseling so that the borrowers can manage the fund effectively to increase their standard of living. It is expected that women's saving and loans program can be 
developed in accordance with the provisions of Islam. Interest system can be replaced by profit and loss sharing system which is very appropriately applied to small and micro enterprises.

\section{References}

Adnan, M.A., Ajija, S.R. (2015). The Effectiveness of Baitul Maal Wat Tamwil in Reducing Poverty the Case of Indonesian Islamic Microfinance Institution. Humanomics 31 (2), pp.160-182.

Akyuwen, Roberto, Krisna Wijaya, dan I D G. S. (2010). Teori dan Praktek Keuangan Mikro di Indonesia. (S. P. UGM, Ed.).

Ala, A. B. (1996). Kemiskinan dan Strategi Memerangi Kemiskinan. Yogyakarta: Liberty..

Atal, Vidya. (2015). Say at Home, or Stay at Home? Policy Implications on Female Labor Supply and Empowerment. Review of Economics of the Household, Vol. 15, Issue 4, pp 1081-1103.

Baridwan, Z. (n.d.). Intermediate Accounting. Yogyakarta: Penerbitan STIE YKPN.

BPS. (2014). Meta DataSubditStatistik Kerawanan Nasional. internet. Retrieved from http://bps.go.id/menutab.php?tabel=1\&kat=1\&id_ subyek $=23$

Hamid. (1986). Recording by seminary, Dalam Kredit Pedesaan di Indonesia. Mubyarto dan Edy Sunandi Hamdi (EDS).Yogyakarta: BPFE

Herdiansyah, H. (2012). Metodologi Penelitian Kualitatif untuk Ilmu-Ilmu Sosial. Jakarta: Salemba Humanika.

Mariyanti, T., Mahfudz, A.A. (2016). Dynamic Circular Causation Model in Poverty Alleviation: Empirical Evidence from Indonesia. Humanomics 32 (3), pp. 275-299. 
Kuncoro, M. (2009). Metode Riset Untuk Bisnis dan Ekonomi (3rd ed.). Jakarta: Erlangga.

Kuncoro, M. (2011). Metode Kuantitatif, Teori dan Aplikasi Untuk Bisnis dan Ekonomi. Yogyakarta: UPP AMP YKPN.

Mughniyah, M. J. (2002). Fiqih Lima Madzab. Jakarta: Lentera.

Primiana, I. (2009). Menggerakkan Sektor Rill UKM dan Industri.

Qardhawi, Y. (n.d.). Peran Nilai dan Moral dalam Perekonomian Islam. Jakarta: Robani Press.

Sakai, M. (2010). Growing Together in Partnership: Women's Views of the Business Practices of an Islamic Savings and Credit Cooperative (Baitul Maal wa Tamwil) in Central Java Indonesia. Women's Studies International Forum 33 (4), pp. 412-248.

Samuelson, P. A. dan W. D. N. (n.d.). Makro Ekonomi. Jakarta: Erlangga. Setyagraha. (2014). BPS: Jumlah Penduduk Miskin 28,55 Juta Orang. Retrieved from http://www.antaranews.com/berita/412182/bpsjumlah-penduduk-miskin-2855-juta-orang

Sevillia, C. G. (1993). pengantar metode penelitian. Jakarta: Universitas Indonesia.

Sidokumpul, D. is resulted by customer of P. M. P. (n.d.). No.

Sulistyastuti, D. R. (2004). Dinamika Usaha kecil dan Menengah (UKM) Analisis Konsentrasi Regional UKM di Indonesia 1. Development of Economi Journal, 9(2), 1-43.

Suyanto, B. (2013). Anatomi Kemiskinan dan Strategi Penangananya: Fakta kemiskinan Masyarakat Pesisir, Kepulauan, Perkotaan dan Dampak dari Pembangunan Indonesia. Malang: Intrans Publishing.

Tim Penyusun Kamus Pusat Pembinaan dan Pengembangan Bahasa.Kamus Besar Bahasa Indonesia(1999). (2nd ed.). Jakarta: Balai Pusaka

Uyanto, Stansius S. (2009). Pedoman Analisis Data Dengan SPSS. Yogyakarta, Graha Ilmu. 
Yusuf, Yusbar, D. (2010). Implikasi Program Nasional Pemberdayaan Masyarakat (PNPM) Mandiri Pedesaan terhadap Pendapatan Pedagang Kecil di Kecamatan Langgam Kabupaten Pelalawan Propinsi Riau tahun 2007-2010.

Wahyudi, I. Realizing Knowledge Sharing in Strategic Alliance: Case in Islamic Microfinance. Humanomics 31 (3), pp. 260-271. 
20 Ana Zahrotun Nihayah

Vol. 2 No. 1, January - April 2017 


\section{Shirkah Author Guidelines}

Shirkah currently offers two routes to submit manuscripts. We highly recommend to submit the articles which are made using OJS (Open Journal System). Feel free register as author soon through visiting http:// shirkah.or.id/index.php/home/user/register. The authors may directly send their manuscripts, along with their resume, to shirkahiainsurakarta@ gmail.com. Please prepare your manuscripts, using following guidelines:

1. Manuscript must be written in English. Submitted articles should not have been published or be under review for publication with another journal.

2. Manuscript's length is about $15-20$ pages, typed in one-half spaced on A4-paper size.

3. Manuscript must include an $150-200$ word abstract and keywords.

4. Manuscript must be arranged as follows: Title, Name of Author, E-mail address, Abstract, Keywords, Introduction (including method if any), Discussion, Conclusion, References.

5. Manuscript's titles not more than ten words.

6. Manuscript must be submitted in Microsoft Word or RTF.

7. Arabic words should be transliterated according to the style of International Journal of Middle Eastern Studies.

8. Manuscript references are preferably derived from the up-to-date references.

9. The author's resume should be submitted separately, consisting of at least full name, institutional address, phone number, areas of studies, and recent publications (if any).

10. Shirkab use APA Style 6th edition (2010) as reference format writing. We suggest the use of a reference manager software such as Mendeley, Zotero, and Endnote at templating the citation style. APA Style to be used is as follows: 


\section{Book with single author}

Swann, G. M. Peter. (2014). The Economics of Innovation an Introduction. Cheltenhum \& Northampton: Edward Elgar.

in-text citation: (Swann, 2014)

\section{Articles in reference books}

Alatas, S. F. (2006). Islam and the Science of Economics in Abu Rabi', I.M. The Blackwell Companion to Contemporary Islamic Thought. USA: Willey-Blackwell (pp. 587-606).

in text citation: (Alatas, 2006)

\section{E-Book}

Hackett, Rosalind (2007). "Religous Dimentions of War and Peace: Introduction.” Dalam Gerrie ter Haar dan Yoshio Tsuruoka (Ed.), Religion and Society: An Agenda for the 21st Century (h. 3-6). Retrieved from http:// brill.nl.

in text citation: (Hackett, 2006)

\section{Master's thesis, from a commercial database}

McNieI, D. S. (2006). Meaning through narrative: A personal narrative discussing growing up with an alcoholic mother (Master's thesis). Available from ProQuest Dissertations and Theses database. (UMI No. 1434728)

in text citation: (Mc Niel, 2006)

\section{Doctoral dissertation, from an institutional database}

Adams, R. J. (1973). Building a foundation for evaluation of instruction in higher education and continuing education (Doctoral dissertation). Retrieved from http://www.ohiolink.edu/etd/

in text citation: (Adams, 1973) 


\section{Doctoral dissertation, from the web}

Bruckman, A. (1997). MOOSE Crossing: Construction, community, and learning in a networked virtual world for kids (Doctoral dissertation, Massachusetts Institute of Technology). Retrieved from http:/www-static. cc.gatech.edu/--asb/thesis/ in text citation: (Bruckman, 1997)

\section{Journal article with No DOI}

Bourkhis, K., and Nabi, M. S. (2013). Islamic and conventional banks' soundness during the 2007-2008 financial crisis. Journal Metrics, 22(2), 68-77.

in-text citation: (Bourkhis \& Nabi, 2013).

\section{Journal article with DOI}

Ichwan, M. (2012). The Local Politics Of Orthodoxy: The Majelis Ulama Indonesia in the Post-New Order Banten. Journal Of Indonesian Islam, 6(1), 166-194. doi:http://dx.doi.org/10.15642/JIIS.2012.6.1.166-194

In text citation : (Ichwan, 2012)

\section{Abstract as citation}

Hasan, N. (2012). Islamist Party, Electoral Politics And Da'wah Mobilization Among Youth : The Prosperous Justice Party (PKS) in Indonesia. Journal of Indonesian Islam, 6(1), 17-47. Abstract from http:// jiis.uinsby.ac.id/index.php/jiis/article/view/97

in text citation : (Hasan, 2012)

\section{Mass media article}

Sahal, Akhmad (2014, March 2). Kiai Sahal dan Realisme Fikih.Tempo Magazine, p. 120.

in text citation : (Sahal, 2014) 


\section{Research report}

Fisher, B. S., Cullen, F. T., \& Turner, M. G. (2000). The Sexual Victimization of College Women. Research Report.

in text citation : (Fisher, Cullen, Turner, 2000)

\section{Monograph}

Routray, Bibhu Prasad (2013), National Security Decision-Making in India (RSIS Monograph No. 27). Singapura: Rajaratnam School of International Studies.

in text citation : (Routray, 2013)

\section{Proceeding article}

Sudibyakto, Hizbaron, D.R., \& Jati, R (Ed.) (2009), Proceeding International Seminar Disaster Theory, Research and Policy. International seminar held by Sekolah Pascasarjana, Universitas Gajahmada, Yogyakarta, 8-9 Desember 2009.

in text citation : (sudibyakto and Jati, 2009)

\section{Paper conference/seminar/symposium}

Janutama, Herman Sinung (2011). "Kraton dan Hubungan Antar Agama." Paper presented in Seminar Kraton dan Panatagama held by Center for the Study of Islam and Social Transformation (CISForm), Yogyakarta, 17 November.

in text citation :(Janutama, 2011)

\section{Online article in web}

Shiva, (2006, February). Bioethics: A Third World Issue. Native-web. Diperoleh dari http://www.nativeweb.org/ pages/legal/shiva.html

in text citation : (Shiva, 2006) 


\section{Online research report}

Kessy, S. S. A., \& Urio, F M. (2006). The contribution of microfinance institutions to poverty reduction in Tanzania (Research Report No. 06.3). Retrieved from Research on Poverty Alleviation website: http://www. repoa.or.tz /documents_storage/Publications/Reports/06.3_Kessy_and_ Urio.pcif

in text citation : (kessy and urion, 2006)

\section{Holy book}

Qur an, $2(25)$

In text citation : (Q. al-Baqarah 2:25).

\section{Encyclopaedia}

Graycar, Adam (1992). Social Welfare Policy. Dalam Mary Hawkesworth dan Maurice Kogan (Ed.), Encyclopedia of Government and Politics (Vol. 1). London: Routledge.

in text citation : (Graycar, 1992)

\section{Interview}

Sultan Hamengkubuwono X (interview, 2011, April 19)

in text citation: (Hamengkubuwono, 2011)

\section{Documentary film}

Steijlen, Fridus (2008). A Day in the Life of Indonesia [documentary film, 58 minutes]. Leiden: KITLV Press.

in text citation : (Steijlen, 2008) 
Vol. 2 No. 1, January - April 2017 